\title{
Pan-European Grading Scales: Lessons from National Systems and the ECTS
}

\section{TERENCE KARRAN}

[This is an electronic version of an article published in Higher Education in Europe, Vol. 30, No. 1, April 2005. Higher Education in Europe is available online at: http://www.informaworld.com]

ABSTRACT: This article assesses the impact of the Bologna Process on the grading schemes of EU member countries. In light of some problems regarding the implementation of the European Credit Transfer system (ECTS), the author proposes further reforms and offers some elements of a unified grading system for European higher education. The author explores the variation among Europe's grading systems and the resulting lessons learned are shared here. Lastly, this article also argues that principles of justice and fairness, deemed central to academic freedom, are best upheld by the use of a unified grading system at national and European levels.

\section{Introduction}

This paper provides a preliminary comparative analysis of the grading schemes in universities in the 24 nations of the newly extended European Union (Cyprus was excluded as part of it is controlled by Turkey which is outside the EU). The rationale for this work is three fold. First, and most significantly, as a major lever for integration within the Bologna Process, all European Universities are being encouraged to use the norm referenced European Credit Transfer System. More than one thousand higher education institutions in Europe now use ECTS [Reding, 2003], leading its advocates to claim that "The tools it uses are tried and tested and have been shown to be effective. The principles on which it is based are sound" [Adams, 2000, p. 19]. However Sullivan's case study on the use of ECTS to facilitate an exchange between a Swedish and UK university concluded that "neither is ECTS grade transfer the simple matter that university literature promoting SOCRATES purports, nor does the transferred grade reflect a similar level of achievement to that which the home university claims to assume” [2002, p. 73] and complained about the misleading "veneer of validity, reliable and standard maintenance” of ECTS. Cross-sectional work by Karran [2003], has also found ECTS to be flawed in calculation and ad hoc in operation, endorsing the recent finding by Reichert and Tauch [2003] that "ECTS as a tool is undergoing rapid and farreaching extensions before it has been properly understood in its original form in many institutions. ... the system is still applied in a very rudimentary or haphazard fashion to student exchange and credit transfer”[p.67]. Similarly Haug has observed: “foreign grades are not just numbers that can be calculated by applying a mathematical formula, but a message that needs first to be understood in the original system and in a second stage interpreted by users in their own system. Simple 
mathematical formulas with their claim to universality are nothing but a fallacious oversimplification of a reality they fail to capture” [Haug, 1997, p.2]. Systems to transfer grades should acknowledge and build on the rich diversity of EU higher education, unlike the current mechanistic system, which masks rather than explores this diversity. Hence a further rationale for this analysis, is to provide some quantitative flesh to inform and enrich the bare bones approach offered by systems such as ECTS, and increase knowledge and awareness of grading systems used in Europe. This aspiration is particularly pertinent to the U.K. h.e. sector, given that Reichert and Tauch found that "academic staff awareness of the Bologna Process seems to be particularly low in Estonia, Lithuania, Sweden, Germany, Ireland and the United Kingdom (UK has by far the lowest BP awareness score for academics)” [p. 19]. Moreover, the expansion of the European Union in May 2004, has meant that universities in the 15 nations that previously constituted the Union now have to familiarize themselves with the h.e. systems of the new ten nations, in order to facilitate student mobility within the enlarged European higher education area.

Secondly, as part of the quality assurance agenda within higher education in the U.K., there have been studies of the vagaries of the U.K. grading system to determine (inter alia) why there are different distributions of degree grades between different subjects and universities. Yorke et al [2002], for example, found that 22\% of U.K. first degree awards in Mathematics were at first class honours level, while the comparable figure for first class honours in Law degree awards was only $4.1 \%$, and that this variation appeared to have little relationship (if any) to any other identifiable measure of input. Further work by the same group demonstrated that "the honours degree classification is considerably less robust that its supporters would prefer” [Yorke et al 2004, p.411]. Similarly, Woolf and Turner [1997] conducted an investigation based on student records from seven institutions and found that when students' results were re-classified using the systems of universities other than their own, $15 \%$ were allocated to a degree classes which differed from the actual award made in the students' home institutions. Furthermore Parlour [1995], following an analysis of results on a modular degree programme, concluded “except in the most limited circumstances, it is impossible to define rules that can ensure that the British honours degree classification process conforms to the basic principles of comparative justice”[p.37]. This work lead to calls for a grade-related criterion common grading scheme [Hornby, 2003] and even the abandoning of the honours scheme [Elton, 2004, Macfarlane, 1998], while a recent comprehensive U.K. study commissioned to examine national policy relating to measuring student achievement and degree classifications concluded that "the existing honours degree classification system has outlived its usefulness and is no longer fit for purpose” [Scoping Group, 2004, p.4]. Given these apparent problems with the U.K. system, it may be useful to examine grading systems elsewhere to see 
whether changes in the U.K. system, bringing it nearer to those systems used in the EU, might lead to improvements.

Thirdly, this attempt at a preliminary comparative analysis of the EU h.e. grading schemes, has been undertaken because, as Norcini and Shea [1997] point out, "If the results of the licensure and certification or credentialing process are to be useful, valued and taken seriously, a body of evidence relating to the credibility of the standards and to its comparability over time and forms must be developed" [p.39]. Additionally, on a more general level, as Teichler [1996] has noted “Analysis of any issue in higher education is enriched by broad knowledge from various countries. .... And comparisons are indispensable for understanding a reality shaped by common international trends, reforms frequently based on comparative observation, as well as growing trans-national activities and partial supra-national integration in higher education” [p.462f].

\section{Methodology}

To undertake the analysis, the following data was gathered from 24 EU nation states:

- The national grading system;

- The verbal description of those grades, in the native language;

- The verbal description of those grades, translated into English;

- A percentage equivalent for those grades;

- The number of times re-sits are allowed for failed assessments;

- Whether the reassessment marks is awarded without penalty.

This data was gathered from various sources. First, via the following organisations:

- The UK National Recognition Information Centre (http://www.naric.org.uk/);

- The European Network of Information Centres (http://www.enic-naric.net/);

- The World Education Services International Grade Conversion Guide For Higher Education (http://www.wes.org/gradeconversionguide/);

- The International Association of Universities Higher Education Systems Database (http://www.unesco.org/iau/whed.html.

This information was augmented by data from the relevant government ministries (for example, the Ministerio de Educación y Ciencia in Spain) and accrediting organizations (for example the Akkreditierungsrat in Germany), gathered via their websites and through email contact. Finally the data was then checked against the details provided by websites of individual universities in the EU nation states. Once the data was gathered, it was emailed to the ECTS co-ordinators in the individual nation states, to verify its accuracy. The summary tables are shown in the Appendix.

Gathering this information on the grading systems, their verbal descriptions in the native language and English, and the percentage equivalents was problematic. Often the grading system is 
indicative, with variations between different subjects in the same university, and between different universities in the same state, although in countries where grades are determined by national law, there is less discretion to deviate. There are variations in the grade descriptions also, although often these are not great - for example one university might describe a grade as "Very Good", while another might use the description “Especially Good.” However, direct translations of a grade descriptor into English can fail to accommodate the national, cultural and academic nuances associated with that grade, which may differ from the "Very Good" used elsewhere. In addition, some universities in some nations (Belgium, Finland, Portugal) use a Latin description of the grade (Summa Cum Laude, Magna Cum Laude, etc.) along with the national description, while others do not. Moreover, because of implementing the Bologna Process, and as a result of national policies, some countries (e.g. Spain and the Slovak Republic) are in the process of changing their grading systems. However, the greatest difficulty arises in trying to calculate a percentage equivalent, which can act as a common denominator for the grades. First, because universities in some states never convert to percentages, this is most prevalent where the number of grades is small (e.g. Sweden). Secondly, because even where universities do provide percentage equivalents for their grades, they differ in the percentage equivalents that they use. Where variation in the grades, their descriptions, and their percentage equivalents did occur, data was gathered from as many universities as possible (made easier by the fact that most, if not all, have institutional websites), and then compared to identify the most commonly used grading system, description and percentage equivalents. Consequently the information on the individual nation states provided in the appendix is a best possible approximation gathered from most common usage, but from which individual universities may (and will) vary.

Hence, a preliminary, but crucially important point, concerns the extent of within nation variation in the calculation of grades. For example, in the U.K. it is universally accepted that, irrespective as to the subject or institution, a student with a final grade percentage over $70 \%$ (however this is computed) will be awarded a first class honours degree. By contrast, in France, the highest grade "Excellent" can be awarded if a student's scores more than 16 or 18 out of 20, depending on the University and/or the Faculty. Similarly, in Sweden there is no grading system determined by law, so each university is free to use their own system within certain limits. Faculties of Engineering have their own system within which students are awarded 3 (pass), 4 (pass with honours lower grade) or 5 (pass with honours upper grade), where 5 is the highest grade. Faculties of Arts and Sciences have their own system, which uses two grades - pass and pass with honours. This variation confirms the findings of a study of the degree classification systems in Australia, Denmark, Germany, Hungary, Ireland, Italy, Norway, Sweden, the USA and the UK commissioned by the U.K. Higher Education Quality Assurance Agency which found "Despite 
extensive comparative work at European level into all manner of aspects of higher education as part of the Bologna process, assessment, like the content of courses, is very much left up to individual countries' own schemes” [Denholme, 2004, p.4] and that "It is striking from the comparisons with other countries how the UK education system in general places enormous emphasis on ensuring standards are comparable, Compared to some of the other higher education systems considered in this paper, UK higher education pays far more attention to issues of quality and standards” [p.45].

\section{Analysis of the Variation in Grading Systems.}

Data on the process of how grades were determined was not requested. However, the same sources used to gather information on grading systems also offer detailed descriptions of the national systems. Although there are variations in the national grading systems, virtually without exception they all operate criterion referenced systems, determining a student's grade by comparing his or her achievements with criteria for learning outcomes and standards for particular levels of performance. The goal being to grade student achievement against objective reference points that are independent of the size or composition of the cohort being assessed. Practice varies in the extent to which these criteria and standards are explicit and clearly stated. Some universities (and national agencies) provide explicit templates, indicating the level of knowledge expected from each student at each point in the grading system. There are minor exceptions to this general rule of criterion referencing - at present Spanish universities use a form of norm referencing for the award of their highest grade, and the 'Matricula de Honor' may not, by law, be awarded to more than $5 \%$ of students. The predominance of criterion referencing in the grading systems of Universities in EU nations, and the recent growing emphasis put on the use of learning outcomes within the Bologna process by the Berlin Communiqué, renders problematic the norm referenced rationale of the ECTS, if coherent integration of European higher education is to be achieved.

With the exception of Sweden, universities in all EU states use a numeric system of grading, allied to the use of grade descriptors. However, in addition to variation in the use of grades within nation states, there is great variation between the grading systems of nation states. For example, universities in Finland use two grading scales, which range from 5 or 3 (highest) to 1+ (lowest), Denmark's scale ranges from 13 (highest) to 6 (lowest), but there is no grade 12, while Italy's pass grades range from $30+$ to 18 . However, the majority of grade scales are ascending, that is the higher the grade, the higher the mark, although there are some exceptions - Austria, Germany, the Czech Republic, Ireland, Malta and the U.K., although the latter three apply a grading system based directly on ascending percentage values. The systems operating in Ireland, Malta and the U.K., are unusual in using aggregated percentage scores (rather than grades) to determine degree classifications. Generally, there is no predominant grading system within the EU, the most 
common are the 1 (lowest) to 10 (highest) scale, which is used in five nations, and the 1 to 20 scale, which is also used in five nations.

In respect of the number of pass grades which can be awarded within each system, again there is no common pattern. However, it is unusual for grade scales to be symmetric about the pass grade - in all states bar one, there are more grades above the pass grade than below it. Sweden has only 2/3 pass grades, as does the Czech Republic, while within the German grading system, there are up to 11 different pass grades which could be recorded. Again there is no common denominator, although nine nations use a system providing 4 grading categories, with seven nations using a four point scale, seven nations using a five point scale and four nations using a six point scale. However, most grading systems have, at the top of their range, a category reserved for the most excellent, for example, in the Flemish part of Belgium students scoring the maximum value of 20, get the award of Met de grootste onderscheiding met felicitaties van de Examencommissie (With full praise/with highest honours, with congratulations of the Board of Examiners). However, there are variations in how this is highest grade is awarded. In Spain, under the old grading system, by law the highest grade of Matricula de Honour (Matriculation with Honours) was only awarded to the top five percent of students. In Latvia, although the grading systems runs from 1 to 10 , and Grade 8 Lsoti Labi (Very Good) is the normal maximum grade. Grades 9 Teicami (Excellent) and 10 Izcili (With Distinction) are reserved for especially advanced students who demonstrate knowledge that is substantially higher than that expected for the course (e.g. the student has read research-level literature or been involved in research in the relevant field). Similarly, in Italy, the top mark of 30, can be awarded con lode/cum laude and, exceptionally, con lode e pubblicazione which implies publication of a thesis.

At the bottom end of the scale, most nations have a minimum "Satisfactory" or "Sufficient" grade (although Greece and Sweden do not). Between the minimum pass and the very highest grades, virtually all nations have grades representing “Good” and "Very Good”. However, the degree of differentiation within these grades, which are likely to be those awarded to the majority of students, varies considerably from one country to the next. Some national systems (e.g., Germany, Latvia, Lithuania, Netherlands, Poland) have more than one "Satisfactory" grade, and some nations also split the "Good” and "Very Good” categories into finer gradations, while the Danish system grades performance as being “Below Average”, “Average” and “Above Average”, with higher grades being awarded on the basis of both excellence and independence.

The problems of attempting to calculate percentage equivalents for the different grades was alluded to above. However, although not definitive, such conversion into percentages provides data about the size of the different grading categories. As would be expected, in some instances, the higher grade categories are smaller in size. However, as usual, there are exceptions - such as the 
Czech Republic and Estonia, where the grade limits (as measured in percentages) are similar throughout the different grades on the scale, while in Hungary, the highest two grades "Excellent" (Jeles) and “Good” (Jó) are larger than the "Fair” (Közepes) and "Satisfactory” (Elégséges) grades. Converting to percentages also enables a comparison of the pass mark, although it many cases (e.g. Finland and Sweden), it is very difficult to estimate, Although variation exists, by far the most common pass mark borders on the equivalent of 50\% (i.e. between $48-51 \%$ ), and is used by more than half the EU nations. A pass mark equivalent to $55 \%$ or higher is used by six nations, and at the other end of the scale a pass mark in the $40-45 \%$ range is used by four nations including the U.K. Most nations have only one fail grade, variously described as "Fail", "Not Sufficient," Unsatisfactory", or "Poor". However, some systems allow for the possibility of the possibility of retrieval through deliberation, and others discriminate between various levels of failure.

Information on the number of re-sits allowed and whether the re-sit mark counted was requested, but not always provided, so that a full set of responses is not available. Nevertheless, the data available pointed to a wide variety of practices. For example, there is an Italian tradition that students can decide if they wish accept the mark they have obtained or if they want to re-sit examinations even if they have not failed, and they can re-sit examinations at least once and often more than once. By contrast, in Denmark, if students fail, they have 3 attempts to pass. Missing attempts are mentioned on students' score sheets, but not counted in the total average, so many students, if they cannot get good marks in a test, choose to give back a blank sheet obtaining a zero (00), and opt to re-sit the examination. If a student cannot pass with three attempts, the University can give dispensations based on individual judgments and after four attempts the University has to gain permission from the Ministry to allow another re-sit, but this is granted more or less automatically. In Finland, Germany and Latvia (and, one suspects, elsewhere) there are no common national rules about re-sitting examinations, and universities provide their own regulations, although normally students can re-sit examinations twice. Despite these differences in regulations concerning how many, and under what circumstances, re-sits were allowed, virtually all the different systems allowed the full re-sit mark to stand.

This preliminary analysis raises some interesting questions. More particularly, if one wished to achieve better integration of European higher education by constructing a new pan European grading system based on usual and common practice across the EU, as revealed in the tables in the Appendix, what would its major features be? Such a grading scale would be criterion referenced against the achievement of agreed learning outcomes, with five or more pass grades, of which one would be reserved for the very best students, but which would allow different categories among the average and good students (by far the largest groups) to be readily discerned. The grading system would be ascending and either based on a 1-10 or 1-20 scale, with each scale category equal in size. 
The pass mark would be $5 / 10$ or $10 / 20$, above which there would be a satisfactory grade, and students would have the right to at least two re-sits without penalties for re-assessment.

\section{Lessons for the UK and the EU}

The study shows that, when compared with the rest of Europe, the U.K.'s grading system is not typical - very few other nations utilize percentage scores that are then aggregated into grades. The use of percentages in determining grades gives the process a veneer of statistical respectability which differs from the practice, as McLachlan et al [2000] note "there is a widespread illusion that essays are traditionally marked on an interval scale, expressed in percentages, on which arithmetical operations can be carried out. However, essays are marked on an ordinal scale, in which the rank categories are determined by a kind of gestalt perception, sometimes reinforced by criterion guidelines” [p.790]. Moreover, as Dalziel [1998] opines "very basic problems arise from any attempt to use numerical data to represent performance. These problems are most obvious when applied to the practices of adding scores together (in some form) to produce final marks” [p.353]. Hence any problems that occur with using percentages as raw scores are further compounded by variations in the mode of aggregation, both between and within U.K. universities, and the absence of “a clear rationale for the grading scale(s) and algorithm(s) that have been chosen” [Yorke, 2001, p.16]. For example Simonite [2000] found that “classification systems based on selected results favour students whose performance is variable ... students who perform consistently will expect to receive poorer degree classifications than other students who have the same mean level of achievement but who perform less consistently” [p.207]. Examining the use of percentage scales, Hornby [2003] concluded that their use “for assessing students' work is seriously flawed. ... the use of percentage scales leads to inequities that are hard to justify” [p.451]. Moving to European style grades should lessen such inequities for, as Bridges et al [1999] found, there is "evidence of discipline-related marking behaviour when percentages are used ... (but that) ... differences between subjects are less marked when grading systems are used” [p.298].

In addition, the U.K. system has a limited number of degree classifications when compared with most other EU nations. The Dearing Report contended that "while the classification made sense in a small homogenous system where the general classification said something meaningful about a student's achievements, it no longer provided useful information” [NICHE, 1997, p.140]. Endorsing this view, Winter [1993] has asserted that "the classified honours degree and the grading process which underpins it is an interesting historical growth whose roots stretch deep into the past and whose branches ramify widely into our current culture, but on educational grounds it is indefensible" [p.375]. The use of broader range of grade scales would address some of these criticisms, given that, as work by Yorke et al [2000] found "the use of grading scales (of 16 or 20 
points, for example) seems to spread out the performances in subjects characterized by narrow percentage ranges” [p.13]. This was underlined by work by Bridges et al [2002] which discovered that "the use of a grade scale tends to encourage a greater spread of marks, provided that the grade scale is not calibrated to a percentage scale” [p.42]. Hence adopting a wider grading scale, similar to those used in other European states, would address some of the known problems of the U.K. degree classification system, as well as encourage further integration within the European higher education area.

Two further areas of difference where the U.K. might usefully adopt European practice concern the pass mark, and the ability to retrieve failure. Defining where the pass/fail cutoff should occur is clearly problematic, irrespective as to the method of grading. However, given the extended use of explicit learning outcomes within UK degree programs, it may be difficult to justify awarding a pass where the candidate achieves less than half the learning outcomes, more particularly where graduation is allied to professional competence, as for example, in law or medicine. It is worth noting that the theory paper of the UK driving test requires that candidates get 30 out of 35 questions correct (86\%) to pass, while students in higher education are required only to secure grades of $40 \%$ to demonstrate they have sufficient knowledge of a particular subject to be awarded an honours degree (albeit third class). Increasing the pass mark to $50 \%$ or its grade equivalent would not disadvantage students, provided changes were made to reassessment regulations. Currently, in most UK universities one re-sit is allowed and the maximum mark that may be awarded for a unit upon reassessment is $40 \%$, a practice described by one ECTS National Counselor as "odd, because it looks as if the student is cursed for life for not achieving the learning outcomes once, for whatever reason.” Given that the main purpose of assessment is to enable students to demonstrate their mastery of specific knowledge and skills, whether they achieve this at the first or second attempt in no way diminishes their abilities, for which they should therefore be accorded the same grades as other students demonstrating the same level of competence. Applying a penalty to success via a second attempt, as the current UK system does, constitutes a disincentive to striving for excellence among students who fail at the first attempt.

The analysis shows that the level of convergence between the differing examination systems among the nation states is greater than might be expected, given the number of states and their diverse histories, suggesting that creating and implementing a European wide system of grading could be technically possible. Morrison et al [1997] argue that "A Europe wide uniform mark scale would ensure that all universities could quickly appraise the academic profile of a visiting student by glancing at his or her achievements to date, calibrated in uniform marks” [p.412]. A Europewide uniform criterion referenced grade scale would differ from the current norm-referenced ECTS, which defines the rate of exchange between pairs of universities for individual students but does not 
act as a common currency for academic credit. Moreover, the calculation of ECTS originally centred on the total workload which the contact hours of a course generated, but is now moving towards the achievement of learning outcomes. Hence it makes sense to introduce a criterion referenced grading scheme which would measure the achievement of these goals. Any new system would need to address the academic customs, grading processes and protocols of all the 25 states within the enlarged EU, rather than the original group of nations for whom ECTS was designed.

The creation of a common framework would also require states to examine and eradicate the current anomalies within grading methods at national level, as it is difficult to see how any supra national scheme can operate fairly and equitably when there is so much variation in the grading systems within individual nations. Hence implementing a common grading system would also have a positive effect on higher education quality assurance processes at national level, and enable benchmarking and sharing of good practice between nation states. For example, U.K. universities use a system of external examiners who operate within a agreed code of practice established by the national quality assurance agency for higher education to help institutions to assure and maintain academic standards and ensure that their assessment processes are sound, fairly operated and in line with the institution's policies and regulations. Such a system is unknown in many other nation states, where there are few administrative checks to guarantee that assessment procedures are applied fairly and uniformly within universities in the awarding of degrees. However, at the Bologna Process meeting in Berlin in 2003, the h.e. ministers recognized that robust quality assurance processes were "at the heart of the setting up of a European Higher Education Area” and committed themselves "to supporting further development of quality assurance at institutional, national and European level”[2003, p.3]. Nevertheless introducing a common grading system, and ensuring it is applied uniformly in individual states via assurance agencies could be problematic if it is construed as an infringement of academic freedom.

\section{Impact on Academic freedom}

Since the time of Humboldt, if not before, university professors have long argued the need for personal academic freedom and fiercely guarded their independence. For example, Altbach [2001, p.205] has opined that "academic freedom is at the very core of the mission of the University”. Similarly, institutional autonomy has been a defining characteristic of a university and has included freedom with respect to appointing academic staff, determining the subject curricula, admitting students, and awarding them qualifications, etc. Consequently, universities have been less regulated than other traditional areas of government funded activity. For example, in the U.K. (and elsewhere) individual academics are free to decide how students' work should be graded, while their institutions are likewise free to determine how students' grades are translated into different 
degree classifications. Within the United Kingdom, under the 1988 Education Reform Act (Section 202) academic freedom within pre-1992 universities is safeguarded by the University Commissioners who are tasked:

- to ensure that academic staff have freedom within the law to question and test received wisdom, and to put forward new ideas and controversial or unpopular opinions, without placing themselves in jeopardy of losing their jobs or privileges they may have at their institutions

- to enable qualifying institutions to provide education, promote learning and engage in research efficiently and economically; and

- to apply the principles of justice and fairness.

However, as Ashby [1966] has noted: “The question as to what constitutes academic freedom in universities is anything but unambiguous, and the patterns of autonomy which satisfy academics in different countries are very diverse” [p.293]. Nevertheless, although academic freedom may enjoy many forms, most writers on the subject (and their fellow academics) are concerned with asserting and protecting academic freedom, rather than mapping out its limits. One exception is Shils [1995, p.6], who argued that "the justification of academic freedom is that it protects the moral and intellectual integrity of the teacher" but that "there are certain activities performed (or not performed) by academics which are not entitled to the right of academic freedom. These include ... deliberate distortion and favouritism in marking examinations” [p.8]. Continuing to use a particular grading system, in the knowledge that it (dis)advantages one group of students over another, may be less culpable than deliberate favouritism in marking, but is none the less undesirable. As one eminent American scholar has astutely observed: "Academic freedom means a great deal, but it should not mean freedom from responsibility to students” [Kennedy, 1995, p.12]. A unified grading system, at national and European levels, by its very generality, would be more transparent than the existing mix of grading mechanisms. This would make the abuse of academic freedom, through favouritism in marking, much less likely, as well as helping to ensure that the principles of justice and fairness, deemed central to academic freedom in the British context, and elsewhere, are upheld in the interests of staff and students alike.

\section{Conclusion}

The very complex but successful introduction in January 2002 of the Euro currency as a common fiduciary issue to replace the diverse monetary systems that existed, and enable a free flow of goods and services across the European area, demonstrates that such central reforms are both possible and beneficial. In a like fashion, "in a Knowledge Economy, those institutions which stand at the heart of generating knowledge also occupy a central place in that economy” [Neave, 2002, p.331]. 
Hence, to maximize the returns of the emerging European knowledge economy, universities need to make knowledge and qualifications readily portable across borders and between states. The mobility of knowledge would benefit greatly from having a common currency of uniform academic grades and thereby portable qualifications, enabling free flow for the knowledge of its citizens with resultant increases in student and labour mobility. This initial exercise demonstrates a unified grading system is feasible, and would have beneficial integrative effects, yet would affirm rather than erode academic freedom. Hence the author is happy to repeat the plea made by one of the respondents who supplied the data which made this exercise possible: "Could you please conclude your research with a recommendation that Europe needs a pan-European grading scale!”

\section{References}

ADAM, S. (2001), Report For The European Commission: ECTS Extension Feasibility Project accessed from http://europa.eu.int/comm/education/programmes/socrates/ectsrap.pdf on 10 June 2004.

ALTBACH, P. (2001), Academic freedom: International realities and challenges, Higher Education, 41, p.205-219.

ASBY, A. (1966), Universities, British, India, African, (Cambridge, Mass, Harvard University Press)

BRIDGES, P H., BOURDILlON., B., COLLYMORE, D., COOPER, A., FOX, W., HAINES, C., TURNER, D., WOOLF, \& YORKE, M. (1999), Discipline-related marking behaviour using percentages : a potential cause inequity in assessment, Assessment and Evaluation in Higher Education, 24(3), p.285-300.

BRIDGES P., COOPER, A., EVANSON, P., HAINES, C., JENKINS, D., SCURRY D., WOOLF, H., YORKE, M., (2002) Coursework Marks High, Examination Marks Low: Discuss, Assessment \& Evaluation in Higher Education, 27(1), pp.35-48.

CONFERENCE OF EU HIGHER EDUCATION MINISTERS, (2003) Communiqué: Realising the European Higher Education Area.

DALZIEL, J. (1998) Using marks to assess student performance: some problems and alternatives Assessment and Evaluation in Higher Education, 23(4) pp.251-366.

DENHOLME, J. (2004) Considering the U.K. Honours Degree Classification Method - available online at: http://www.qaa.ac.uk/scottishenhancement/events/Assess_seminar/Jane_Denholm.pdf ELTON, L. (2004) Should classification of the UK honours degree have a future?, Assessment and Evaluation in Higher Education, 29(4), pp.415-422. 
HAUG, G. (1997) Capturing the Message Conveyed by Grades: Interpreting Foreign Grades, World Education News and Reviews, 10(2).

HORNBY, W. (2003) Assessing Using Grade-related Criteria: A single currency for universities, Assessment and Evaluation in Higher Education, 28(4), pp.435-453.

KARRAN, T. (2003), Achieving Bologna Convergence: Is ECTS failing to make the grade?, Conference Proceedings, EADTU Annual Conference: E-Bologna: Progressing the European Learning Space, Madrid , 6-8 November

KENNEDY, D. (1995), Another Century's End, Another Revolution for Higher Education, Change, 27(3), pp.8-15.

MACFARLANE, B. (1998), Degree Classifications: Time To Bite The Bullet, Teaching in Higher Education, 3(3), pp.401-405.

MCLACHAN, J. \& WHITEN, S. (2000), Marks, Scores and Grades: Scaling and Aggregating Student Assessment Scores, Medical Education, 34(2), pp.788-797.

MORRISON, H., COWAN, P., HARTE, S., (1997), The Impact Of Modular Aggregation On The Reliability Of Final Degrees And The Transparency Of European Credit Transfer, Assessment \& Evaluation in Higher Education, 22(4), pp.405-17.

NATIONAL COMMITTEE OF INQUIRY INTO HIGHER EDUCATION (1997) Higher Education in the Learning Society (London, HMSO).

NEAVE, G. (2002), Academic Freedom in an age of globalisation, Higher Education Policy, 15, p.331-335

NORCINI, J. \& SHEA, J. (1997), The Credibility and Comparability of Standards, Applied Measurement in Education, 10(1) pp.39-59.

PARLOUR, J, (1995), A Critical Analysis of Degree Classification Procedures and Outcomes, Higher Education Review, 28(2), pp.25-39.

REDING, V. (2003,) We need to implement wholeheartedly the Bologna process Keynote Address, Berlin conference on Higher Education, Berlin, 18 September 2003.

REICHERT, S. \& TAUCH, C. (2003), Trends 2003: Progress towards the European H.E. Area, (EUA: Brussels)

SCOPING GROUP ON MEASURING AND RECORDING STUDENT ACHIEVEMENT (2004), Measuring and Recording Student Achievement, (London: Universities UK)

SHILS, E. (1995), Academic Freedom and Permanent Tenure, Minerva: A Review of Science, Learning and Policy, 33(1), pp.5-17.

SIMONITE, V. (2000), The Effects of Aggregation Method and Variations in the Performance of Individual Students on Degree Classifications in Modular Degree Courses, Studies in Higher Education, 25(2), pp.197-209. 
SULLIVAN, K. (2002), Credit and grade transfer within the European Union's SOCRATES programme: unity in diversity or head in the sand?, Assessment and Evaluation in Higher Education, 27(1), pp. 65-74.

TEICHLER, U. (1996), Comparative Higher Education: Potentials and Limits, Higher Education, 32(4), pp.431-465.

WINTER R. (1993,) Education or Grading? Arguments for a Non-subdivided Honours Degree, Studies in Higher Education, 18(3), pp.363-377.

WOOLF, H. \& TURNER, D., (1997), Honours classifications: the need for transparency, The New Academic, 6(3), pp.10-12.

YORKE, M. (2001), Assessment: A Guide for Senior Managers, LTSN Generic Centre Assessment Series No. 1, (York: LTSN).

YORKE, M., BARNETT, G., BRIDGES, P., EVANSON, P., HAINES, C., JENKINS, D., KNIGHT, P., SCURRY, D., STOWELL, M., WOOLF, H., (2002), Does Grading Method Influence Honours Degree Classification?, Assessment and Evaluation in Higher Education, 27(3), pp.269 279.

YORKE, M., BARNETT, P., EVANSON, P., HAINES, C., JENKINS, D., KNIGHT, P., SCURRY, D., STOWELL, M., WOOLF, H., (2004), Some effects of the award algorithm on honours degree classifications in UK higher education, Assessment and Evaluation in Higher Education, 29(4), pp.401-413.

YORKE, M., BRIDGES, P., WOOLF.H., (2000), Mark distributions and marking practices in UK higher education Some challenging issues, Active Learning In Higher Education, 1(1), pp.7-27. 
Appendix 1

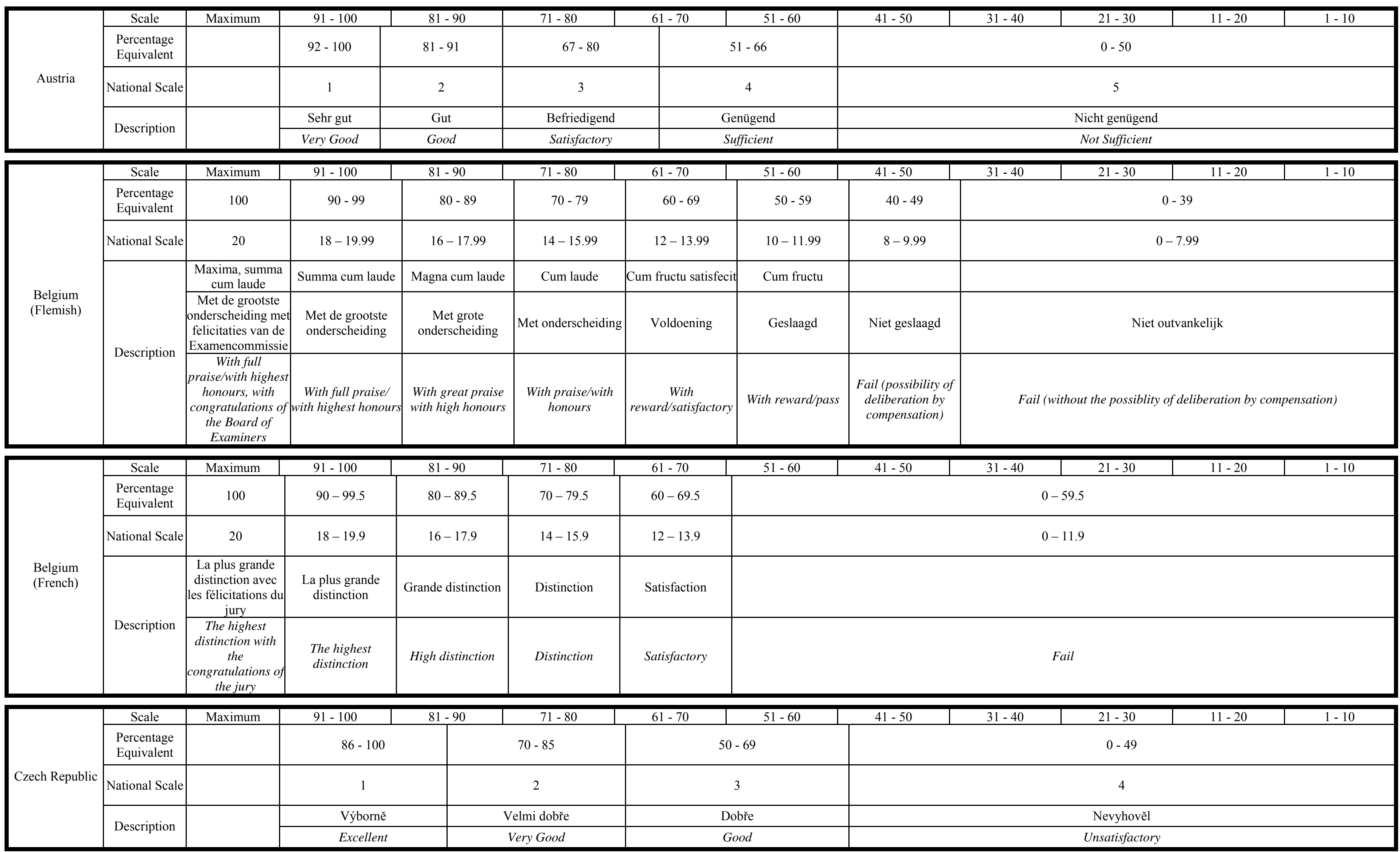




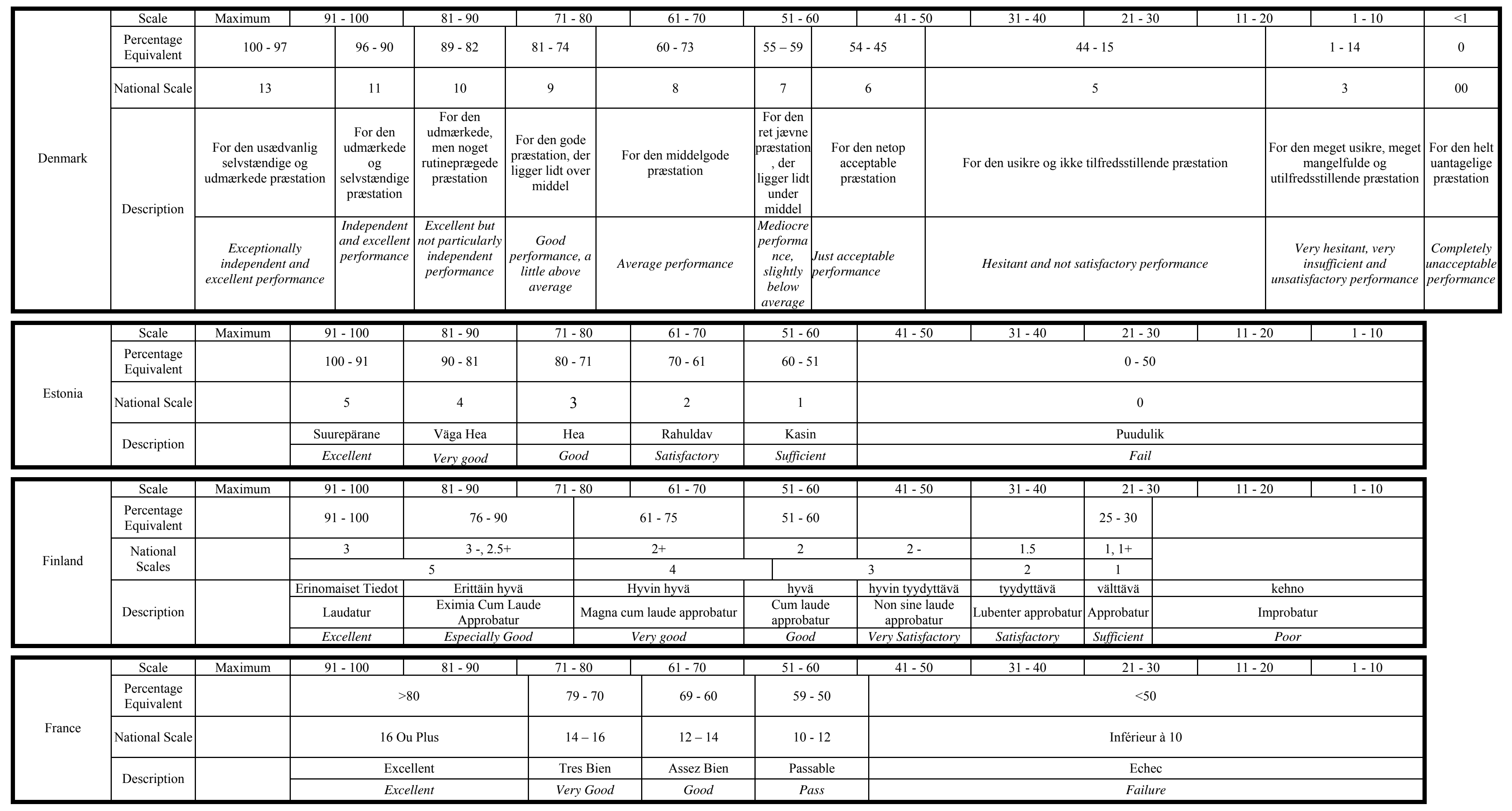




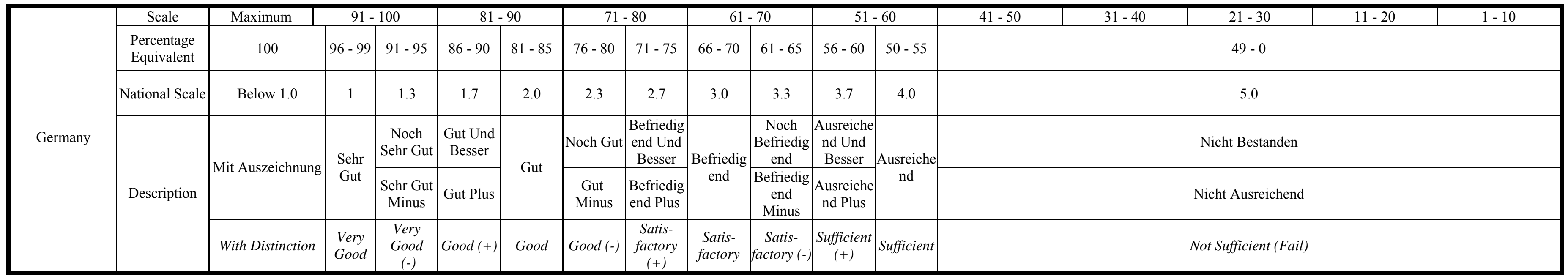

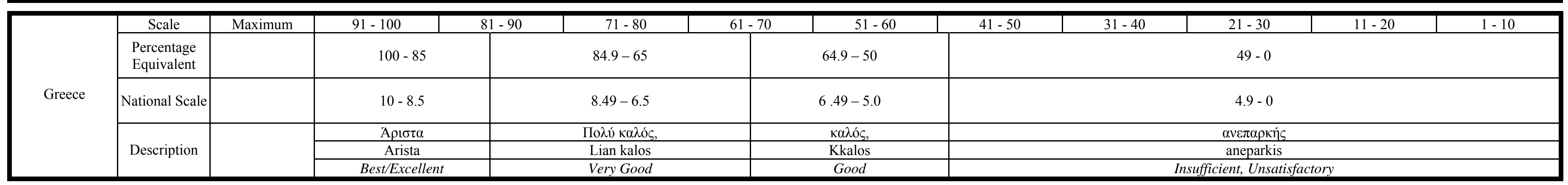

\begin{tabular}{|c|c|c|c|c|c|c|c|c|c|c|c|c|}
\hline \multirow{5}{*}{ Hungary } & Scale & Maximum & $91-100$ & $81-90$ & $71-80$ & $61-70$ & $51-60$ & $41-50$ & $31-40$ & $21-30$ & $11-20$ & $1-10$ \\
\hline & $\begin{array}{l}\text { Percentage } \\
\text { Equivalent }\end{array}$ & & $86-100$ & & $71-85$ & $61-70$ & $51-60$ & & & $0-50$ & & \\
\hline & National Scale & & 5 & & 4 & 3 & 2 & & & 1 & & \\
\hline & \multirow{2}{*}{ Description } & & Jeles & & Jó & Közepes & Elégséges & & & Elégtelen & & \\
\hline & & & Best/ Excellent & & Good & Fair & Satisfactory & & & Unsatisfactory & & \\
\hline
\end{tabular}

\begin{tabular}{|c|c|c|c|c|c|c|c|c|c|c|c|c|c|}
\hline \multirow{4}{*}{ Ireland } & Scale & Maximum & $91-100$ & $81-90$ & $71-80$ & & & $51-60$ & $41-50$ & $31-40$ & $21-30$ & $11-20$ & $1-10$ \\
\hline & $\begin{array}{l}\text { Percentage } \\
\text { Equivalent }\end{array}$ & & \multicolumn{3}{|c|}{$>70 \%$} & \multicolumn{2}{|c|}{$60-69$} & $50-59$ & $40-49$ & \multicolumn{4}{|c|}{$0-39$} \\
\hline & National Scale & & \multicolumn{3}{|c|}{ Ist Class Honours } & \multicolumn{2}{|c|}{$\begin{array}{l}\text { Upper Second Class } \\
\text { (2.1) Honours }\end{array}$} & $\begin{array}{c}\text { Lower Second Class } \\
\text { (2.2) Honours }\end{array}$ & $\begin{array}{c}\text { Class } 3 \\
\text { Honours/Pass }\end{array}$ & \multicolumn{4}{|c|}{ Fail } \\
\hline & Description & & \multicolumn{3}{|c|}{ Excellent an excellent piece of work, only marginal mistakes } & \multicolumn{2}{|c|}{\begin{tabular}{|c|}
$\begin{array}{c}\text { Very Good: some } \\
\text { mistakes, but overall } \\
\text { still outstanding } \\
\text { work }\end{array}$ \\
\end{tabular}} & \begin{tabular}{|c|} 
Good: good and \\
sound understanding \\
but some basic \\
mistakes
\end{tabular} & $\begin{array}{l}\text { Pass: the work } \\
\text { fulfils the } \\
\text { requirements }\end{array}$ & \multicolumn{4}{|c|}{ Fail } \\
\hline \multirow{5}{*}{ Italy } & Scale & Maximum & $91-100$ & $81-90$ & $71-80$ & & & $51-60$ & $41-50$ & $31-40$ & $21-30$ & $11-20$ & $1-10$ \\
\hline & $\begin{array}{l}\text { Percentage } \\
\text { Equivalent }\end{array}$ & $97-100$ & $90-96$ & $80-8 c$ & $64-7$ & & $60-63$ & & & & & & \\
\hline & National Scale & $\begin{array}{l}30,30 \text { e lode } \\
30 \text { con lode e } \\
\text { pubblicazione }\end{array}$ & $27-29$ & $24-26$ & $19-23$ & & 18: & & & & & & \\
\hline & \multirow{2}{*}{ Description } & Excellent & Molto Buono & Buons & \multicolumn{2}{|c|}{ Soddisfacente } & $\begin{array}{c}\text { Sufficie } \\
\text { nte }\end{array}$ & \multicolumn{6}{|c|}{ Respinto } \\
\hline & & Excellent & Very Good & Good & \multicolumn{2}{|c|}{ Satisfactory } & $\begin{array}{c}\text { Sufficie } \\
n t\end{array}$ & \multicolumn{6}{|c|}{ Fail } \\
\hline
\end{tabular}




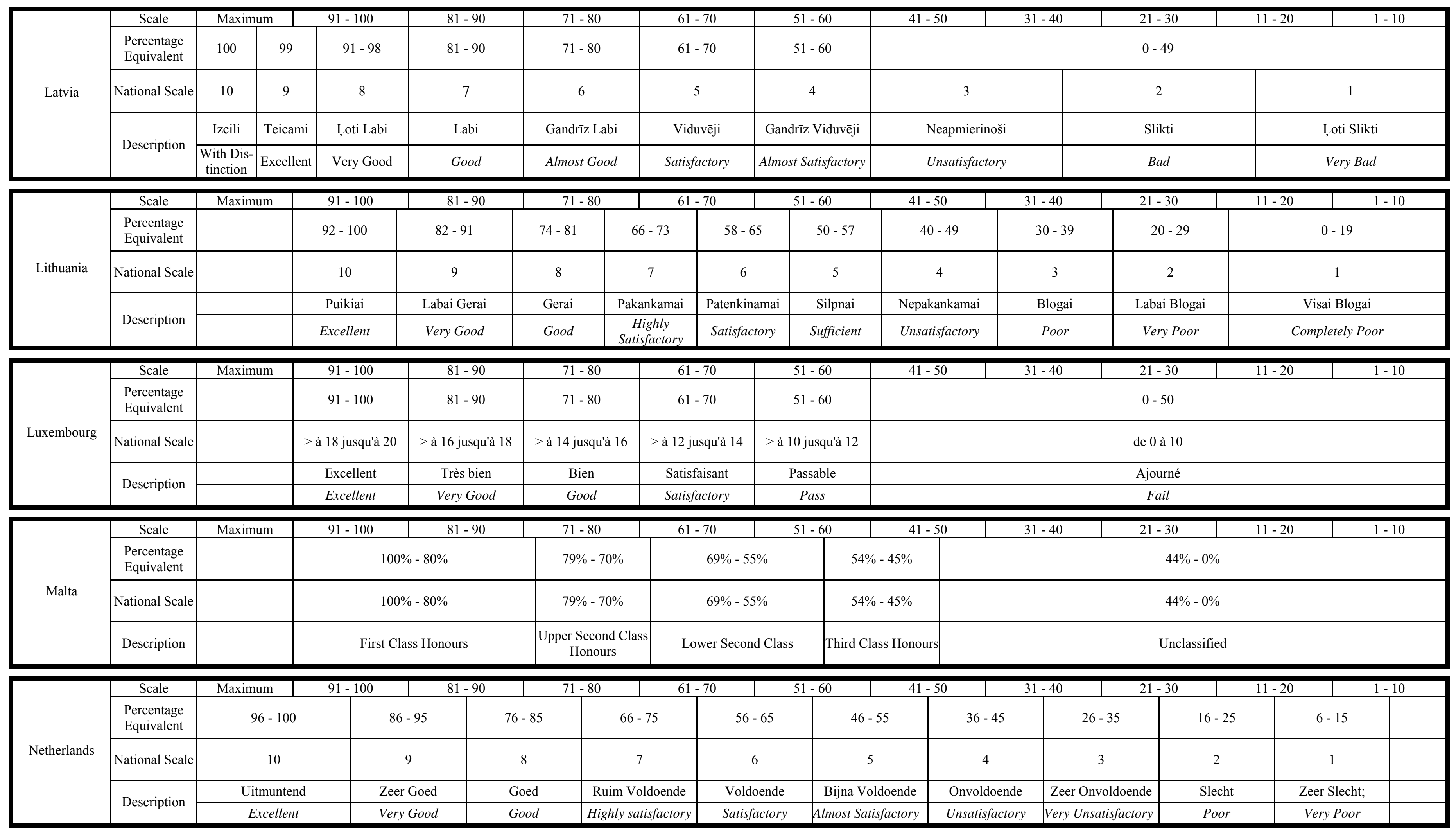




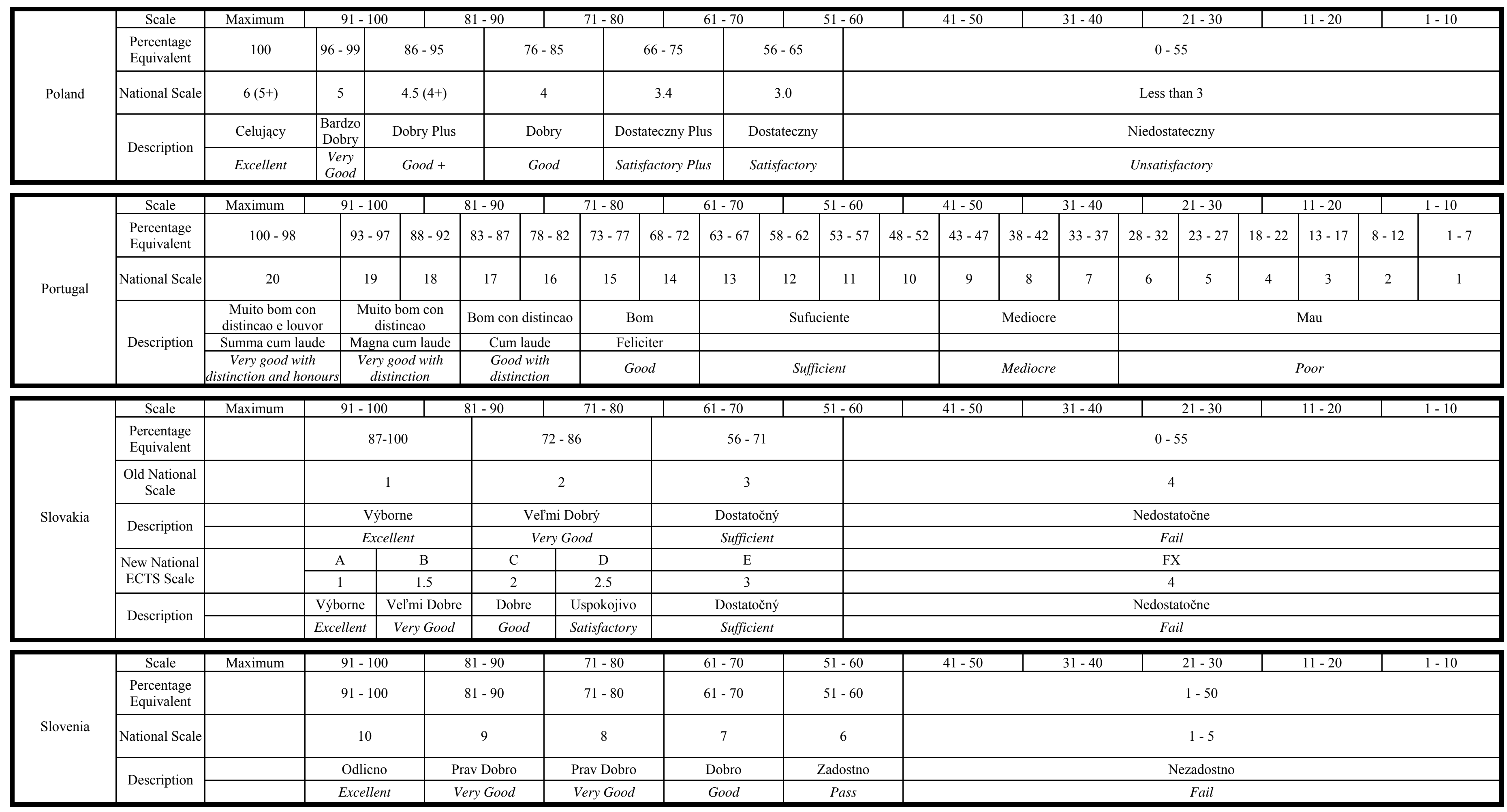




\begin{tabular}{|c|c|c|c|c|c|c|c|c|c|c|c|c|}
\hline \multirow{8}{*}{ Spain } & Scale & Maximum & $91-100$ & $81-90$ & $71-80$ & $61-70$ & $51-60$ & $41-50$ & $31-40$ & $21-30$ & $11-20$ & $1-10$ \\
\hline & $\begin{array}{l}\text { Percentage } \\
\text { Equivalent }\end{array}$ & 100 & $90-99$ & \multicolumn{2}{|c|}{$70-89$} & \multicolumn{2}{|c|}{$50-69$} & \multicolumn{5}{|c|}{$0-49$} \\
\hline & $\begin{array}{l}\text { Old National } \\
\text { Scale }\end{array}$ & 10 & $9-9.9$ & \multicolumn{2}{|c|}{$7-8.9$} & \multicolumn{2}{|c|}{$5-6.9$} & \multicolumn{5}{|c|}{$0-4.9$} \\
\hline & Deccrintion & $\begin{array}{l}\text { Matricula de } \\
\text { Honour }\end{array}$ & Sobresaliente & \multicolumn{2}{|c|}{ Notable } & \multicolumn{2}{|c|}{ Aprobado } & \multicolumn{5}{|c|}{ Suspenso } \\
\hline & . & \begin{tabular}{|c} 
Matriculation with \\
Honours
\end{tabular} & Outstanding & \multicolumn{2}{|c|}{ Notable } & \multicolumn{2}{|c|}{ Approved Pass } & \multicolumn{5}{|c|}{ Fail } \\
\hline & $\begin{array}{c}\text { New National } \\
\text { Scale }\end{array}$ & 4 & 3 & \multicolumn{2}{|c|}{2} & \multicolumn{2}{|c|}{1} & \multicolumn{5}{|c|}{0} \\
\hline & \multirow{2}{*}{ Description } & Excelente & Muy Bien & \multicolumn{2}{|c|}{ Bien } & \multicolumn{2}{|c|}{ Suficiente } & \multicolumn{5}{|c|}{ Suspenso } \\
\hline & & Excellente & Very Good & \multicolumn{2}{|c|}{ Good } & \multicolumn{2}{|c|}{ Sufficient } & \multicolumn{5}{|c|}{ Fail } \\
\hline \multirow{5}{*}{ Sweden } & Scale & Maximum & $91-100$ & $81-90$ & $71-80$ & $61-70$ & $51-60$ & $41-50$ & $31-40$ & $21-30$ & $11-20$ & $1-10$ \\
\hline & $\begin{array}{l}\text { Percentage } \\
\text { Equivalent }\end{array}$ & & \multicolumn{2}{|c|}{$>80$} & \multicolumn{3}{|c|}{$51-79$} & \multicolumn{5}{|c|}{$<50$} \\
\hline & National Scale & & \multicolumn{2}{|c|}{ Väl godkänd } & \multicolumn{3}{|c|}{ Godkänd } & \multicolumn{5}{|c|}{ Underkänd } \\
\hline & \multirow{2}{*}{ Description } & & \multicolumn{2}{|c|}{ Väl godkänd } & \multicolumn{3}{|c|}{ Godkänd } & \multicolumn{5}{|c|}{ Underkänd } \\
\hline & & & Pass witl & tinction & & Pass & & & & Fail & & \\
\hline & Scale & Maximum & $91-100$ & $81-90$ & $71-80$ & $61-70$ & $51-60$ & $41-50$ & $31-40$ & $21-30$ & $11-20$ & $1-10$ \\
\hline & $\begin{array}{l}\text { Percentage } \\
\text { Equivalent }\end{array}$ & & & $>70 \%$ & & $60-69$ & $50-59$ & $40-49$ & & & & \\
\hline U.K. & National Scale & & & it Class Hon & & $\begin{array}{c}\text { Upper Second Class } \\
\text { (2.1) Honours }\end{array}$ & $\begin{array}{c}\text { Lower Second Class } \\
\text { (2.2) Honours }\end{array}$ & $\begin{array}{c}\text { Class } 3 \\
\text { Honours/Pass }\end{array}$ & & & & \\
\hline & Description & & Excellent an excel & piece of wor & arginal mistakes & \begin{tabular}{|c|}
$\begin{array}{c}\text { Very Good: some } \\
\text { mistakes, but overall } \\
\text { still outstanding } \\
\text { work }\end{array}$ \\
\end{tabular} & \begin{tabular}{|c|} 
Good: good and \\
sound understanding \\
but some basic \\
mistakes
\end{tabular} & $\begin{array}{l}\text { Pass: the work } \\
\text { fulfils the } \\
\text { requirements }\end{array}$ & & & & \\
\hline
\end{tabular}

Dr Terence Karran, University of Lincoln, October $20^{\text {th }} 2004$ 